\title{
Effect of Value Chain Management Practices on Performance of Medium and Large Scale Retail Outlets in Nakuru County, Kenya
}

\author{
Naomi Thuku* Henry Kombo \\ Department of Business Administration, Egerton University, PO Box 536, Egerton
}

\begin{abstract}
Current research in the field of strategy suggests that efficient and effective value chain management practices are critical in enhancing organizational performance. However, past empirical studies have not focused on the effect of value chain management practices and organizational performance, particularly in retail outlet sector. The overall objective of this study was to determine the effect of value chain management practices on performance of medium and large scale retail outlets in Nakuru County. The study was based on the resource-based view theory. The study employed correlational research design. The population of the study was 43 medium and large scale retail outlets. Census study was carried out among 43 medium and large scale retail outlets in Nakuru County, Kenya. Primary data was collected using close-ended questionnaires. The results revealed positive and significant relationship between value chain management practices and organizational performance. It is concluded that while internal value chain activities need to be the key vision of value chain management practices in firms, all value chain management practices dimensions should be combined for a greater increase in organizational performance. Keywords: Value chain management practices, Organizational performance, Resource-based view theory, Medium and Large scale retail sector, Kenya.
\end{abstract}

DOI: $10.7176 / \mathrm{EJBM} / 11-14-10$

Publication date:May $31^{\text {st }} 2019$

\subsection{Introduction}

There is increased sophistication in the shopping pattern of consumers, which has resulted in big retail chains coming up in the international arena. Global players like Wal-Mart and Tesco have set pace in the way retailing is done to meet the ever changing consumer taste and preferences. Kenya and the rest of the world have not been left behind. The retail growth is being driven by changes in lifestyle, surge in income and the advent of devolution, which is supported by favourable demographic patterns (Liedholm 2001).

Moreover, as buyer-value relationship competition increases, the challenges associated with producing a product and service to the right place at the right time at the lowest cost increases. Organizations begin to realize that it is not enough to improve efficiencies within an organization, but their whole value chain has to be made competitive. Value chain analysis becomes an important tool to measure value creating processes of a company (Porter 1985). This research gives emphasis on the impact of value chain management practices on organization performance and firm competitiveness.

Value chain management practices are broken down into three main components namely, supplier relationship, internal value chain activities and customer relationship which are found to compare with best practices globally (Kaplinksy \& Morris 2001). Supplier relationship involves strategically planning for and managing all interactions with third party organizations that supply goods and / or service to an organization to maximize value of those interactions (Chen, Paulraj \& Lado 2004). Internal value chain activities are interdependent building blocks by which firms deliver products to the customer, earn profit/ margins as well as develop advantages over rivals (Porter 1985). Finally, customer relationship entails managing customer interactions with a view to identifying the most valuable customers, trying to personalize activities to their needs and then establish and maintain long-term and profitable relationships (Dawes \& Swailes 1999).

The outlook for the retail sector is strong and Kenya is starting to be seen as an ideal point of entry for launching retail outlets and consumer goods distribution into East and Central Africa. Only about $16.8 \%$ of the Kenyan population currently falls into the middle class, but that should grow strongly. Kenya's retail market comprises a mixture of modern retail outlets that supply consumer goods from major international firms and informal traders or family-run concerns that sell more basic goods. The country's Vision 2030 includes plans to improve the efficiency of the retail market and once the formal retail expands, there should be significant opportunities for logistics service providers (Price waterhouse Coopers Kenya 2013).

In spite of the theoretical linkages between value chain management and organizational performance, past empirical studies have not focused on the effect of value chain management and organizational performance, particularly in retail outlet sector. In Kenya, Ghonar (2015) sought to ascertain the influence of the value chain activities in the performance of Safaricom Limited, Kenya. Aguko (2014) carried out study on value chain performance of beer brewing industries in Kenya. Therefore, this study sought to examine the effect of value chain management practices on performance of medium and large scale retail outlets in Nakuru County, Kenya.

The rest of the paper is organized as follows: the next section reviews related literature and research 
hypothesis. This is followed by an overview of the research methodology, which discusses the research design, target population, data collection, measurement of variables and data analysis techniques. The fourth section presents the results and discussions. The fifth section presents conclusions of the study.

\subsection{Literature Review}

Strategic management literature suggests that firms make strategic choices regarding the focus of their core resources on value chain activities and the various buyer - supplier relationships and the linkages between them that enhance competitive advantage and performance (Newbert 2007). Hence, this study adopted resource based view (RBV) of the firm which is one of the most widely accepted theoretical perspectives in the field of strategic management in explaining organizational performance (Barney 1991; Priem \& Butler 2001).

Hardacre and Collins (2008); Gabriel (2006) define value chain management as the examination of processes and uncertainties from beginning to end of the chain in an integrated manner in order to optimize overall value. Kaplinsky and Morris (2001) summarized the elements of value chain as design, production, marketing, distribution and support to get the product to the final user. Porter described the value chain framework as an interdependent system or network of activities, connected through linkages which, if managed well, could be a relevant source of good performance (Pathania-Jain 2001).

According to Marete (2010), the purpose of a value chain is to achieve whole and seamless interaction among stakeholders to create a win-win situation. Comprehending these relationships and their various impacts to the value of an organization's products and services is a vital component to the success of the organization. Value chain has been modified and the application of ideas to development issues incorporated with increased modernization and globalization. As Gereffi and Korzeniewicz (1994) put it, attention is now shifting to global commodity chain (GCC). Subsequent approaches have focused predominantly on the value network of Porter in terms of the relationships and linkages between firms, rather than solely at value creating functions within a firm. These relationships and linkages, that is, supplier relationship, customer relationship and internal value chain activities form the basis of value chain management practices (Kaplinksy \& Morris 2001).

In value chain management, relationships are key if the objectives of a business are to be met (Corsten $\&$ Felde 2005). Supplier relationship management is analogous to customer relationship management. Customers have become crucial for every organization due to the competitive environment, that business operate in. Buyersupplier relationships change while they develop. Just as a company needs to develop relationships with its supplier, it also needs to foster relationship with its customers. The desired outcome is a win-win relationship where both parties benefit; leading to increased organization performance (Dawes \& Swailes 1999).

Value chain activities are related by linkages within the value chain. Linkages can lead to competitive advantage through optimization and coordination (Porter 1998). Firms seeking to have a better cost performance in the industry must strive to cut costs associated with value chain activities, while the ones which wishes to outperform its competitors through quality will have to perform its value chain activities better than them (Capon 2008).

Porter (1985) pointed out factors that impact organizational performance and value chain management activities in organizations. They include linkages, interrelationships, location and timing. Medium and large scale retail outlets must optimize the linkages in the value chain in order to achieve competitive advantage and sustained performance. They not only undertake activities in supplying goods and services to the customer but they also impact those in marketing, and vice versa. Empirical research has consistently found that value chain management practices contribute positively to organization performance.

Ghonar (2015) carried out a study on value chain activities on organizational performance of Safaricom Limited, Kenya and concluded that organizations that carry out value chain management practices in their organizations often enjoy improved performance in terms of higher profits, better responsiveness in the market, long-term market dominance and long-term competitive advantage. Loko and Opusunju (2016) studied the relationship between value chain and performance in agro allied small and medium scale enterprise in Sokoto, Nigeria. They alluded that the ability of management to co-ordinate linkages often reduces cost or enhances differentiation. Co-ordination of linkages implies that a firm's cost or differentiation can result from the way linkages are managed as well as the efforts to reduce cost or improve performance in each value activity individually. They also recommended that agro SMEs should continue to improve on value chain activities since it contributes significantly to the performance of the agro SMEs in Sokoto, Nigeria.

Olhager (2012) investigated the role of decoupling points in value chain management and found that there is one dominant customer order decoupling point (CODP) along the material flow of the value chain. From a company perspective, the CODP can be positioned inside their manufacturing operations or it can be positioned at the suppliers (first tier or even further upstream in the value chain), at the interface with the supplier (raw material inventory), at the border towards the customers (at some finished goods inventory) or even further downstream in the supply chain.

In a study on value chain analysis and organizational performance of beer manufacturing companies in Kenya, 
Aguko (2014) demonstrated that an ideal measure must take into account information on both historical organization performance and future organization performance expectations which depend on the actions recently to create strategic alternatives and opportunities. Therefore, the value of the opportunities created relates to past actions and, accordingly, this value should be included in a performance measure as the risk adjusted present value of the opportunities.

A study by Schiebel (2005) on value chain analysis and competitive advantage in telecommunication firms in the United Kingdom indicated that the value chain analysis does not only reveal cost advantages but also brings attention to several sources of differentiation advantage relative to competitors. It equally identifies those activities that are critical to buyer satisfaction and market success. This enables the firm to achieve above-average customer satisfaction that breeds customer loyalty, increased market share and higher profit margin. Based on the above theoretical arguments and empirical evidence, the following hypothesis was proposed:

$\mathrm{HA}_{4}$ Value chain management practices has a positive effect on organizational performance.

\subsection{Conceptual Framework of the relationship between Value Chain Management practices and Organizational} Performance.

The framework for this study examined value chain management practices as the key factor in improving organizational performance in strategic management as illustrated in figure one.

\section{Moderating variable}

\section{Contextual factors}

- Economic conditions

- Legal factors

Independent variable

\section{Value chain management practices \\ Supplier relationship \\ - Manufacturer and supplier \\ - Supplier and retail outlet}

Internal value chain activities

- Primary and support activities

- value chain of firm and supplier channels

Customer relationship

- Retail outlet and customer

\section{Dependent variable}

Organizational performance

- Sales

- Market share

- $\quad$ Number of customers

- $\quad$ Stock level

Figure 1: Relationship between Value Chain Management Practices, Contextual Factors and Organizational Performance.

According to the framework in Figure 1, value chain management practices is the independent variable while organizational performance is the dependent variable. It is expected that efficient value chain management practices in terms of supplier relationship, internal value chain activities, and customer relationship would result in high organizational performance in terms of sales, market share, number of customers and stock level.

However, these variables are affected by contextual factors such as economic conditions, legal factors and company laws. Value chain management practices namely supplier relationship, internal value chain activities and customer relationship have a direct effect on organization performance, which can affect organization performance positively. Relationships in value chains, that is, customer relationship and supplier relationship are characterized by transactions, a vast exchange of information, knowledge, skills and various embedded services for example after sale services. Hence, understanding relationships between members are crucial to enhanced organizational performance. For example, how entry barriers are created and how gain and risks are distributed directly impacts performance (United Nations International Labor Organization 2009).

Urbig (2003) conducted a pilot study to investigate "the implications of the value chain for firm and industry analysis", among selected companies in Berlin. The study revealed that the value chain management practices enables companies' executives to control cost drivers better than the competitors and thus creating above average performance in operational efficiency, profitability, market share, customers' satisfaction, innovations, quality and assets utilization.

Contextual factors namely legal factors, economic conditions and company laws can limit the opportunities 
for organizations to benefit from adopting a value chain management business approach, hence, limit the competitiveness of individual businesses (Marston 2008). Countries have legal bodies that ensure the value chain players adhere to legal laws within which the companies operate to achieve their objectives and sustained organization performance. In Kenya for instance, Consumer Federation of Kenya (COFEK) defends, promotes, develops and regulates consumer rights as guided by the Kenyan constitution and makes it possible for the consumer to get the value for money. One of the most cited studies belongs to Gompers, Ishi and Metrick (2003). They built an index for measuring legal laws using a sample of 1,500 US firms in the 90s. The study demonstrated the existence of a positive relationship between the quality of legal laws and firm performance.

Organization performance indicators, that is, sales, market share and number of customers will be affected by the prevailing economic conditions. The state of the economy of a country (expansion or contraction) determine the setting of the prices of goods and services (low or high), which in turn affects organization performance (Narain \& Singh 2012). Finally, company law and policies assists participants in the value chain to fulfill required rules and regulations. In Japan, Bauer et al. (2008) using the database provided by GMI, showed that companies operating under favorable economic conditions, legal factors and better company laws and policies are more efficient than those operating in harsh economic conditions, legal factors and weaker company laws and policies by up to $50 \%$ annually.

\subsection{Methodology}

\subsection{Research Design}

The study employed correlational research design. The design describes the nature and strength of the relationship between the variables. It was also useful because it was used to make predictions about the variables under study. The study adopted a cross-sectional census survey in that data was collected over a short period from the entire population (Mugenda \& Mugenda 2003).

\subsection{Target Population}

The population of the study comprised of 43 medium and large scale retail outlets in Nakuru County, Kenya. According to Kibera (2007), the criteria used to determine the size of a firm are capital, sales turnover or number of employees but recommends the use of number of employees' criteria as it is information which is readily available to researchers. According to Kibera (2007), the sizes of firms in Kenyan context are classified as micro firms (below 10 employees), small firms (11-50 employees), medium firms (51-100 employees) and large firms (above 100 employees). Therefore, the population of this study comprised of retail outlets which employ above 51 employees.

There are 43 medium and large scale retail outlets in Nakuru County (County Government of Nakuru). Given their small number, all the retail outlets were studied through a census. This focused on the managers of the retail outlets. The list of the firms in the study was identified from the County Government of Nakuru because the Ministry of Finance and Economic Planning maintains records of all businesses in the county.

\subsection{Data Collection}

The study used primary data. Primary data consists of original data gathered by the researcher for the specific purpose of the study at hand (Mugenda \& Mugenda 2003). Data was collected by use of questionnaires administered by the researcher. The close-ended questions provided more structured response to facilitate tangible recommendations. The questionnaire was in the form of Likert scale of 1 to 5 . The unit of analysis was the firm and data was collected at the firm level. For each firm, one respondent filled in a questionnaire. The respondent was the manager of the retail outlets conversant with the organization's value chain management practices and performance.

\subsection{Measurement of Variables}

In this study, the independent variable is value chain management practices while the dependent variable is organizational performance. Borrowing from literature review (Porter 1985), value chain management practices will be measured in terms of supplier relationship, internal value chain activities and customer relationship as conceptualized by (Suhong, Nathan, Nathan, \& Rao 2004). A five point Likert scale ranging from strongly disagree (1), disagree (2), neutral (3), agree (4) and strongly agree (5) was used to measure the variable. A five point Likert scale ranging from very much decreased (1), decreased (2), not changed (3), increased (4) and very much increased (5) was used to measure the variable. Organization performance was measured in terms of sales, market share, number of customers and stock level. These will also be borrowed from (Suhong, Nathan, Nathan, \& Rao 2004).

\subsection{Data Analysis}

Descriptive statistics such as mean and standard deviation were used to summarize the data and describe value chain management practices and organization performance of firms. Pearson's product-moment correlation was 
used to examine the relationship between value chain management practices and organizational performance. To test the hypothesis which predicted that value chain management practices has a positive effect on organizational performance, multiple regression analysis was used. Organizational performance was regressed on the dimensions of value chain management practices that is supplier relationship, internal value chain activities and customer relationship. The following multiple regression model was developed:

$Y=a+\beta_{1} X_{1}+\beta_{2} X_{2}+\beta_{3} X_{3}+\varepsilon$

Where: $\mathrm{Y}$ is the dependent variable (organizational performance), a is constant, $\mathrm{X}_{1}$ is supplier relationship, $\mathrm{X}_{2}$ is internal value chain activities, $X_{3}$ is customer relationship, $\beta_{1-} \beta_{4}$ is regression coefficients and $\varepsilon$ is regression error term

\subsection{Results and Discussion}

\subsection{Response Rate}

The unit of analysis in this study was the organization as each organization has unique sets of value chain management practices and organizational performance. Questionnaires were distributed to 43 companies. After follow-ups, questionnaires from 38 companies were completed and returned in a form usable for analysis, which constituted a response rate of 88 percent. This response rate was considered. According to Mugenda and Mugenda (1993) a response rate of more than $80 \%$ is sufficient for the study.

\subsection{Reliability and Validity}

\subsubsection{Test of Validity}

To ascertain the validity, the researcher used content validity through the development of the scales with the help of the experts in the Faculty of Commerce, Egerton University.

4.2.2 Test of Reliability

The research scales were examined to determine their reliability. This was done using Cronbach's alpha coefficient. The results of the analysis presented in Table 1 show that all the research constructs had alpha coefficients of above 0.7. The overall Cronbach's Alpha coefficient was 0.797. Overall, the instrument met the recommended threshold of 0.7 (Nunnaly 1978) and thus was considered reliable.

Table 1: Reliability Statistics

\begin{tabular}{|c|c|c|}
\hline \multicolumn{3}{|c|}{ Overall Reliability Statistics } \\
\hline \multicolumn{3}{|l|}{ Cronbach's Alpha } \\
\hline .797 & Cronbach's Alpha Coefficients for the Measurement Scales for the Constructs & \\
\hline Cronbach's Alpha & ts for the Measure & for the Constructs \\
\hline Variable & Number of items & Alpha (a) \\
\hline Internal value chain activities & 4 & 0.755 \\
\hline Supplier relationship & 6 & 0.760 \\
\hline Customer relationship & 5 & 0.763 \\
\hline Organizational performance & 4 & 0.794 \\
\hline
\end{tabular}

\subsection{Correlation Analysis}

The study examined how the variables of the study; supplier relationship, internal value chain activities and customer relationship and organizational performance are related (Hypothesis $\mathrm{HA}_{1}$ to $\mathrm{HA}_{3}$ ). The analysis was done using Pearson's correlation matrix. The results are presented in Table 2. 
Table 2: Correlation Matrix for Supplier Relationship, Internal Value Chain Activities, Customer Relationship and Organizational Performance

\begin{tabular}{|c|c|c|c|c|c|}
\hline & & $\begin{array}{l}\text { Supplier } \\
\text { Relationship } \\
\end{array}$ & $\begin{array}{l}\text { Internal Value } \\
\text { Chain Activities }\end{array}$ & $\begin{array}{l}\text { Customer } \\
\text { Relationship } \\
\end{array}$ & $\begin{array}{l}\text { Organizational } \\
\text { Performance } \\
\end{array}$ \\
\hline Supplier & Pearson Corr & elation & 1 & $.653 * *$ & $.267 * * \quad .779 * *$ \\
\hline \multirow{2}{*}{ Relationship } & Sig.(1 Tailed & & .000 & .002 & .000 \\
\hline & $\mathrm{N}$ & 38 & 38 & 38 & 38 \\
\hline $\begin{array}{l}\text { Internal Value } \\
\text { Chain }\end{array}$ & $\begin{array}{l}\text { Pearson } \\
\text { Correlation }\end{array}$ & $.653 * *$ & 1 & $.412^{* *}$ & $.855^{* *}$ \\
\hline \multirow[t]{2}{*}{ Activities } & $\begin{array}{l}\text { Sig.(1 } \\
\text { Tailed) }\end{array}$ & .000 & & .001 & $\begin{array}{l}.000 \\
38\end{array}$ \\
\hline & $\mathrm{N}$ & 38 & 38 & 38 & \\
\hline \multirow{3}{*}{$\begin{array}{l}\text { Customer } \\
\text { Relationship }\end{array}$} & $\begin{array}{l}\text { Pearson } \\
\text { Correlation }\end{array}$ & $.267 * *$ & $.412 * *$ & 1 & $.843 * *$ \\
\hline & $\begin{array}{l}\text { Sig.(1 } \\
\text { Tailed) }\end{array}$ & .002 & .001 & & .000 \\
\hline & $\mathrm{N}$ & 38 & 38 & 38 & 38 \\
\hline \multirow[t]{3}{*}{$\begin{array}{l}\text { Organizational } \\
\text { Performance }\end{array}$} & $\begin{array}{l}\text { Pearson } \\
\text { Correlation }\end{array}$ & $.779 * *$ & $.855 * *$ & $.843 * *$ & 1 \\
\hline & $\begin{array}{l}\text { Sig.(1 } \\
\text { Tailed) }\end{array}$ & .000 & .000 & .000 & \\
\hline & $\mathrm{N}$ & 38 & 38 & 38 & 38 \\
\hline
\end{tabular}

**. Correlation is significant at the 0.05 level (1-tailed).

The results in Table 2 indicate that there is a positive significant relationship between supplier relationship and organizational performance $(\mathrm{r}=0.779, \mathrm{p}<0.05)$. The results in Table 2 also show that there is a positive significant relationship between internal value chain activities and organizational performance $(r=0.855, p<0.05)$. The results in Table 2 also indicate that there is a positive significant relationship between customer relationship and organizational performance $(\mathrm{r}=0.843, \mathrm{p}<0.05)$. Thus the results also reveal that there is a positive and significant relationship between all the dimensions of value chain management practices and performance.

\subsection{Test of Hypothesis}

The testing of hypothesis $\left(\mathrm{HA}_{4}\right)$ concerning the effect of value chain management practices on organizational performance was done using multiple regression analysis. Organizational performance was regressed on the dimensions of value chain management practices that is, supplier relationship, internal value chain activities and customer relationship. The results are presented in Table 3.

Table 3: Multiple Regression Results for Effect of Supplier Relationship, Internal Value Chain Activities and Customer Relationship on Organizational Performance

\begin{tabular}{|c|c|c|c|c|c|}
\hline \multicolumn{6}{|c|}{ Model Summary ${ }^{b}$} \\
\hline Model & $\mathrm{R}$ & R Square & Adjusted R Square & \multicolumn{2}{|c|}{ Std. Error of the Estimate } \\
\hline 1 & $.081 \mathrm{a}$ & .777 & .753 & \multicolumn{2}{|c|}{.32961} \\
\hline \multicolumn{6}{|c|}{ ANOVA $^{\mathrm{a}}$} \\
\hline Model & Sum of Squares & Df & Mean Square & $\mathrm{F}$ & Sig. \\
\hline Regression & 6.604 & 13 & .440 & 10.827 & \\
\hline Residual & 14.373 & 24 & .532 & & \\
\hline Total & 20.977 & 37 & & & \\
\hline \multicolumn{6}{|c|}{ Coefficients $^{\mathrm{a}}$} \\
\hline Model & \multicolumn{2}{|c|}{ Unstandardized Coefficients } & Standardized Coefficients & $\mathrm{t}$ & Sig. \\
\hline & $\mathrm{B}$ & Std. Error & Beta & & \\
\hline (Constant) & 4.885 & .268 & & 3.853 & .000 \\
\hline Supplier & .625 & .173 & .528 & 1.944 & .026 \\
\hline Relationship & & & & & \\
\hline Internal Value & .786 & .341 & .641 & 2.131 & .015 \\
\hline Chain Activities & & & & & \\
\hline Customer & .596 & .197 & .382 & 1.501 & .042 \\
\hline Relationship & & & & & \\
\hline
\end{tabular}

a. Predictors: (Constant), supplier relationship, internal value chain activities, customer relationship.

b. Dependent Variable: Organizational performance 
Model in Table 3 shows effect of value chain management practices on organizational performance. The model shows that R Square is 0.777 , which shows that $77.7 \%$ of the variation in organizational performance is explained by the joint dimensions of value chain management practices. The ANOVA demonstrates test for the combined effect of value chain management practices on organizational performance. The ANOVA results show that the model is significant $(\mathrm{F}=10.827, \mathrm{P}<0.05)$. This indicates that the combined dimensions of value chain management practices; supplier relationship, internal value chain activities and customer relationship have a positive significant effect on performance.

The full regression model in Table 3 can also be interpreted to show how dimensions of value chain management practices affect organizational performance. All the dimensions have significant results. From the unstandardized coefficients in the Table 3, the regression equation below was developed:

$\mathrm{Y}=4.885+0.625 \mathrm{x}_{1}+0.786 \mathrm{x}_{2}+0.596 \mathrm{x}_{3}+\varepsilon$

The unstandardized coefficients show that for every unit increase in supplier relationship, a 0.625 unit increase in organizational performance is predicted holding other variables constant. For every unit increase in internal value chain activities, a 0.786 unit increase in organizational performance is predicted holding other variables constant. For every unit increase in customer relationship, a 0.596 unit increase in organizational performance is predicted holding other variables constant.

The findings of this study are consistent with observations of Porter (1985) that highlights factors which impact organizational performance and value chain management activities in organizations. They include linkages, interrelationships, location and timing. Value chain is not a collection of independent activities, but rather interconnected value chain activities through linkages and interrelationships which are the primary means of achieving competitive advantage and sustained performance.

From the standard coefficients in the Table 3, internal value chain activities has the greatest effect on Organizational Performance which is positive and significant $(\beta=0.641, t=2.131, p<0.05)$, followed by the effect of supplier relationship on organizational performance which is positive and significant $(\beta=0.528, t=1.944$, $\mathrm{p}<0.05)$, and the customer relationship has least effect on organizational performance which is positive and significant $(\beta=0.382, \mathrm{t}=1.501, \mathrm{p}<0.05)$.

The findings are consistent with Ghonar (2015) study which demonstrates that value chain management practices impact a firm's performance. Ghonar (2015) concluded that organizations that carry out value chain management practices in their organizations often enjoy improved performance in terms of higher profits, better responsiveness in the market, long-term market dominance and long-term competitive advantage.

Aguko (2014) demonstrated that an ideal measure must take into account information on both historical organization performance and future organization performance expectations which depend on the actions recently to create strategic alternatives and opportunities. Therefore, the value of the opportunities created relates to past actions and, accordingly, this value should be included in a performance measure as the risk adjusted present value of the opportunities.

\subsection{Conclusion}

The overall objective of this study was to determine the effect of value chain management practices on performance. The results reveal that value chain management practices has a positive and significant effect on organizational performance, which supports hypothesis $\mathrm{HA}_{4}$. Further, regarding the relative influence of the dimensions of value chain management practices on organizational performance, regression results indicate that internal value chain activities has greatest effect on organizational performance, followed by supplier relationship and lastly customer relationship.

Finally, the results show that the joint effect of firm supplier relationship, internal value chain activities and customer relationship on organizational performance is greater than the effect of internal value chain activities alone. This shows that synergizing firm supplier relationship, internal value chain activities and customer relationship initiatives achieves a greater effect on organizational performance than that of internal value chain activities alone. Thus, it is concluded that there is a linkage between value chain management practices and organizational performance; hence, higher levels of value chain management practices would lead to improved organizational performance.

This study has made a contribution in understanding the effect of value chain management practices on organizational performance in a developing country context. However, the study has some limitations. This study adopted a cross-sectional survey. Such studies have limitations on providing explanations on the linkage between variables. Thus, future research should adopt longitudinal research designs in data collection to enhance understanding of the relationship between the value chain management practices and organizational performance.

Moreover, future research should broaden the conceptualization of the resource-based view to include other theories that may give depth to the study. There is also need to cover other factors related to value chain management practices that can impact on organizational performance to a larger extent since the factors used in this study can only explain $77.7 \%$ of the increase in performance. The respondents of this study were executive 
officers and single respondents were used to collect data. To minimize the effect of single respondent bias, future research can use multiple respondents including executive officers and middle managers.

\section{References}

Aguko, S. O. (2014), Value chain analysis and organizational performance of beer manufacturing companies in Kenya, Unpublished MBA Thesis, University of Nairobi, Nairobi.

Barney, J. B. (1991), 'Firm resources and sustained competitive advantage,' Journal of Management 17, 99-120.

Bauer, R., Braun, R., \& Clark, G.L. (2008), "The emerging market for European corporate governance: The relationship between governance and capital expenditure,"1997- 2005, Journal of Economic Geography 8(4), 441-469.

Capon, C. (2008), Understanding strategic management. Prentice Hall, Financial Times, Harlow.

Chen, I.J., Paulraj, A., \& Lado (2004), Strategic purchasing, Supply management and firm performance. Journal of operations Management 5, 86-115.

Corsten, D., \& Felde, J. (2005), "Exploring the performance effects of key-supplier collaboration: An empirical investigation into Swiss buyer-supplier relationships." International Journal of Physical Distribution \& Logistics Management 35(6), 445-461.

Dawes, J., \& Swailes, S. (1999), "Retention san frontiers: Issues for financial service retailers." International Journal of Bank Marketing 17 (1), 36-43.

Gabriel, E. (2006), "Value chain for services - A new dimension of porter's value chain.” The IMS International Journal 34, 1-30.

Gereffi, G. (1994), 'The organization of buyer-driven global commodity chains: How US retailers shape overseas Production networks', in G. Gereffi and M. Korzeniewicz (eds.), Commodity Chains and Global Capitalism. Westport: Greenwood Press.

Ghonar, B. (2015), Strategic management of value chain activities and performance of Safaricom Kenya limited, Unpublished MBA Thesis, University of Nairobi, Nairobi.

Gompers, P., Ishii, J., \& Metrick, A. (2003), “Corporate governance and equity prices.” Quarterly Journal of Economics 118, 107-155.

Hardacre, B., \& Collins, G. (2008), Procurement's role in the generation and capture of value in supply chains.

Kaplinksy, R., \& Morris, M. (2001), A handbook for value chain research. Working paper prepared for the IDRC, Brighton, UK, Institute for Development Studies.

Kibera, F.N. (2007), Introduction to business: A Kenyan perspective. Kenya Literature Bureau, Nairobi, Kenya.

Liedholm, C. (2001), Firm Dynamics: Evidence from Africa and Latin America, World Bank Institute.

Marete, P. K. (2010), Application of Hines value chain model by Kenya medical supplies agency, Unpublished MBA Thesis, University of Nairobi, Nairobi.

Marston, N. (2008), KG fruits: The benefits of collaborating as a 'new generation' producer co-operative; Value chain management (DVD); George Morris Centre.

Mugenda, O., \& Mugenda, A. (2003), Research methods. Quantitative and qualitative approaches. Nairobi: Acts Press.

Narain, R., \& Singh, A. (2012), Role of buyer-supplier relationship and trust in organizational performance. Delhi Business Review 13(2), 73-82.

Newbert, S. L. (2007), Empirical research on the resource-based view of the firm: An assessment and suggestions for future research. Strategic Management Journal 28, 121-146.

Nunnally, J. C. (1978), Psychometric theory (2nd ed.). New York: McGraw-Hill.

Olhager, J. (2012), The role of decoupling points in value chain management. Modelling value: Selected papers of the 1 st international conference on value chain management, 37-47.

Pathania-Jain, G. (2001), Global parents and local partners. A value-chain analysis of collaborative strategies of media firms in India. Journal of Media Economics 14(3), 169-187.

Porter, M.E. (1985), Competitive advantage: Creating and sustaining superior performance. 1st Edition, Free Press, New York.

Price waterhouse Coopers. (2013), Supplier relationship management: How key suppliers drive your company's competitive advantage.

Priem, R. L., \& Butler, R. (2001), Is the resource-based 'view' a useful perspective for strategic management research? The Academy of Management Review 26(1), 22-40.

Schiebel, M. (2005), "Value chain analysis and competitive advantage in telecommunication Linns in the United Kingdom", Unpublished Ph.D Dissertation, Institute of Marketing and Innovation, University of Natural Resources and Applied life Sciences, 2.15.

Suhong, Li., Nathan, B.R., Nathan, T.S., \& Rao, S.S. (2004), The Impact of Supply chain Management practices on competitive advantage and organizational performance. Omega the International Journal of Management Science 34(2006), 107-124. 
United Nations International Labor Organization (UNILO). (2009), Guide for value chain analysis and upgrading. Retrieved from http://www.valuechains.org/dyn/bds/docs/detail/545/6.

Urbig, D. (2.003), "The value chain analysis-implications for firms and industry analysis"; Proceedings of Perspectives in business informatics research (BIR) Berlin-Shaker Verlag; 1-15. 